\title{
RECONSTRUCTION OF CIVIL SERVANT PERFORMANCE ASSESSMENT MODEL IN THE GOVERNANCE OF GORONTALO PROVINCE
}

\author{
Asna Aneta \\ Departement of Administrative \\ Science \\ Gorontalo State University \\ Gorontalo, Indonesia \\ asnaatiek.aneta@ung.ac.id
}

\author{
Maha Atma Kadji \\ Departement of Administrative \\ Science \\ Gorontalo State University \\ Gorontalo, Indonesia
}

\author{
Hais Dama \\ Departement of Administrative \\ Science \\ Gorontalo State University \\ Gorontalo, Indonesia
}

\begin{abstract}
The research aims at reconstructing the model of civil servant performance assessment in a conditional, rational, and practical way to support the governance within the Province of Gorontalo.

The research used qualitative design to do in-depth analysis on the model of civil servant performance assessment at the local governments within the Province of Gorontalo and to identify alternative model of civil servant performance assessment to support the governance within the Province of Gorontalo.

The research shows that the model of civil servant performance assessment at the local governments within the Province or Gorontalo was not consistent, Therefore, reconstruction of the civil servant performance assessment is necessary to support the governance in each of the local government within the Province of Gorontalo. Reconstruction of the civil servant performance assessment was conducted in the following phase : establishment of the annual work plan, formulation and establishment of Civil Servant Performance, Implementation of job description and assessment.
\end{abstract}

Keywords-reconstruction, civil servant, performance assessment

\section{INTRODUCTION}

Local governance, which is oriented on high-quality public service, requires the role and responsibility of high-performing civil servants. Civil servant performance refers to existence of civil servants, who have the necessary competence and achievements that are required for improving the quality of governance and public service. These eventually will lead to the improvement of public satisfaction towards the development programs conducted by the local government.

Through its regulation, the local government continuously encourages the civil servants to optimize their performance. For this, periodical assessment was conducted for the civil servant performance to make sure that the civil servants could do all of the administrative tasks, public service, and development programs in an optimum way. Performance assessment is also a method to get the necessary feedback and to set a plan for corrective actions. Therefore, reconstruction of civil servant assessment model was necessary, and this was conducted by means of a research, which complied with the relevant methodological and scientific norms.

\section{The CONCEPT OF PERFORMANCE}

According to Prawirosentono(1), performance refers to the results of work achieved by an individual or a group of individuals within an organization, based on their authority and responsibility, in the efforts of achieving the organization's objectives in a legal way and in compliance with the existing moral and ethic principles.

Understanding the basic concepts of performance can be obtained by using the engineering approach defines performance and the economic marketplace approach. In view of the engineering approach, performance is defined as a ratio of human resources (input) and the resulting standard units (output). On the other hand, economic market place approach is related to the productivity, based on the use of certain resources(2).

Lenvine et al.(3) proposed three indicators that could be used to measure the performance of a public bureaucracy namely responsiveness, responsibility and accountability.

\section{PERformance ASSESSMENT}

Levine et al.(3) proposed three concepts that could be used to measure performance of a public bureaucracy, namely, responsiveness, responsibility and accountability(4). According to Keban(5), among of the approaches that can be used to measure the performance of local government are managerial and policy approaches, assuming that effectiveness of the local government greatly depends upon the two main aspects, namely Public Management and Policy. Management approach deals with to what extent the managerial functions in the local government have been implemented as efficiently and effectively as possible. The targets are all of individuals responsible for implementing the public policy. In addition, Keban(4) combines both approaches into moral/ethic approach. 
In this context, Keban sees to what extent the local government has paid attention on the aspect of morality. Combination of the two approaches is the target of this moral/ethic approach.

Furthermore, managerial function can be viewed from the managerial lines in charge, namely, whether there have been improvements in the use of managerial skill, system, and work procedures, motivation as well as satisfaction among the employees or officials in the local government. It is necessary to find out whether the approach has contributed to the objective achievement in an efficient and effective way. In addition, performance of the local government is assessed to find out to what extent the functions, tasks, and responsibilities have been manifested in the management and policy programs.

\section{METHOD}

This research used qualitative method with a case study. This study was conducted in Gorontalo Provincial Office of Personnel Management and Gorontalo District Office of Personnel Management. Data collection methods were focused observation, in-depth interview, FGD, and document study. The qualitative data were analyzed interactively and continuously through several systematic steps that consisted of data collection, data reduction, data display, data verification and conclusion drawing.

The research was conducted for three years. In the first year (2014), the research was focused on investigating the model of civil servant performance assessment at the local governments within the Province of Gorontalo. In the second year (2015), the research was focused on reconstructing the model of civil servant performance assessment at the local governments within the Province of Gorontalo, and in the third year (2016), the research was focused on implementing the civil servant assessment model in the governance within the Province of Gorontalo.

\section{RESULT AND DISCUSSION}

\section{A. Reconstruction of Civil Servant Performance Assessment Model}

The model of civil servant assessment in the Province of Gorontalo were presented in this following phase. First, the model of civil servant performance assessment is conducted by an internal team in the local government or external team, both in partial and integrated way to obtain maximum and standardized results of performance assessment. Secondly, formulation of annual work plan and budget plan, as well as operational plan of the government institutions based upon the vision and mission of the leader. The next phase were formulation and determination of civil servant performance target for each civil servant and approval by the superior or assessor. Later phase were Job implementation by each of the civil servant based on the pre-specified Civil Servant Performance Target. Staffing supervision by immediate superordinate in each work unit and assessment at the end of fiscal year, consisting of monitoring of program implementation is the next phase. Confirmation of the Reward and Punishment system, integrated evaluation after the assessment in each work unit and the feedback upon the civil servant performance assessment is the end phase.

When applied at all levels of government in the Province of Gorontalo, the model of civil servant performance assessment is expected to guarantee uniformity in assessment as a reference or legal basis for the implementation, implementation time, assessment indicators/aspects, as well as assessor. In addition, the model is expected to guarantee objective assessment of the local government performance assessment, which in turn will motivate the civil servants to develop their potentials and to contribute for the improvement of local government performance.

\section{B. Implementation of The Civil Servant Performance Assessment Model in The Governance of Gorontalo Province}

Focus Group Disscussion (FGD), which involved the local governments in the Province of Gorontalo, including the Provincial Government of Gorontalo, revealed that all of the government lines had implemented the civil servant assessment method as stipulated in the Government Regulation. The Government Regulation stipulates that civil servant assessment at all levels is conducted once a year.

The values of performance assessment varied from a region to another. For instance, in Gorontalo Municipality, the civil servants have the right to receive the benefits in full amount as long as they meet the disciplinary component, which values sixty percent and the job performance component which values fourty percent. The disciplinary component is measured from the attendance of civil servants at the office during the specified work hours and attendance for specific activities held by the Local Government. The job performance component is measured from the monthly statement of job description implementation which is submitted to the direct supervisor.

In the Local Government of Gorontalo, the benefits for the civil servants are given based on the regent's regulation stipulates that the benefits are based upon the workload and the work location. Civil servants who have the right to received the benefits are those who attend the office and do the job description based on the specified terms. Based on Regent's regulation further stipulates that distribution of the benefits are in effect since January 1, 2015, based on the attendance list recapitulation for December 2014. This shows that the basis for the benefits is merely the attendance, and it seems to overlook the job performance or achievements of the civil servants.

In the Local Government of Bone Bolango, benefits for the civil servants are established in the Regent's Decision on the Benefits for Civil Servants based on the work load in the local government of Bone Bolango, for the fiscal year of 2015. The attachment for the Regent's Division maintains that the criteria for the benefits include loyality, leadership, innovation, public service, teamwork, and disciplinary aspect. This is almost similar to the Local Government of Gorontalo, as the benefit scheme seems to overlook the job performance of the civil servants.

In the Local Government of Boalemo, benefits for the civil servants are specified in the Regent's regulation on the local 
government standard unit price for the fiscal year of 2015. The Regent's regulation maintains that the benefits are given based on the organizational structure and echelon system. Also, it seems to obey the job performance of the civil servants.

In the Local Government of Pohuwato, the benefits are specified in the Regent's Regulation which maintains that elements that determine the civil servants' job performance include (a) knowledge and competence in their job description and other related tasks; (b) skills for implementing the job description; (c) diligence in doing the job description; (e) effectiveness and efficiency in the job implementation, and (f) achievements of the civil servant performance targets, which have been agreed by the Civil Servants and the Direct Supervisor. Unlike the other local governments do, the local government of Pohuwato has included the job performance as a determinant of the benefits.

In the Provincial Government of Gorontalo, the benefits are specified in the Governor's Regulation for the Fiscal Year of 2015. The Governor's Regulation maintains that assessment of the civil servant job performance is based upon 5 indicators, namely discipline, productivity, responsibility, teamwork, and innovation. As Pohuwato Regency does, the Provincial Government of Gorontalo also uses the job performance/ productivity in determining the benefits for the civil servants, despite lack of details.

Despite variation in the policy and implementation, assessment of the civil servant performance in the Province of Gorontalo are generally similar, particularly in the aspect of time, as the assessment is conducted every month. This is not surprising, since the job performance assessment is directly related to the benefit, which is distributed every month, even though payment is realized every three months or month.

Another similarity in common among the local governments in the Province of Gorontalo refers to the model of civil servant performance assessment, which is recommended in the second phase of this research. The local governments in the Province of Gorontalo generally have applied the performance assessment method through the Local Staffing Office. However, most of the assessment had not come into the final phase of the model, namely feedback.
Lack of Feedback phase implies lack of knowledge and awareness of the civil servants on the shortfalls or mistakes, which they do. In the long run, this kind of system will eventually lead to apathies among the civil servants, since they do not know what to correct and what to improve from their job performance. This will eventually result in suspicion among the civil servants, that the assessment is neither fair nor objective. In the end, this condition will lead to decrease of the civil servant performance level.

\section{CONCLUSION}

The distribution of Benefits for the Civil servants, each local government in the Province of Gorontalo determines a policy related to the performance assessment, which is conducted once a month. When it comes to the construction of civil servant performance assessment model to support the governance as recommended in this research, all of the local governments in the Province Gorontalo had not fully implemented all of the phases, particularly the feedback phase.

\section{RECOMMENDATIONS}

The research recommends that all of the local governments in the Province of Gorontalo implement all phases of the civil servant performance assessment model to improve the governance effectiveness.

\section{REFERENCES}

[1] Prawirosentono, S. Employee Performance Policy : Tips for Building a Competitive Organization Ahead of World Trade. Yogyakarta, Indonesia. Economy Faculty Press. 2002. [Kebijakan Kinerja Karyawan : Kiat Membangun Organisasi Kompetitif Menjelang Perdagangan Bebas Dunia]

[2] Widodo, J. (2001). Good Governance : Review of the Dimensions of Bureaucracy Accountability and Control in the Decentralization and Autonomy Era. Surabaya, Indonesia. Insan Cendekia Press. 2001. [Telaah dari Dimensi Akuntabilitas dan Kontrol Birokrasi pada Era Desentralisasi dan Otonomi Daerah].

[3] Lenvine, C.H. Public Administration: Challenges, Choices, Consequences. Scott Foreman/Litle Brown Higher Education: Glenview, Illianos. 1990.

[4] Keban, Y.T. Local Government Performance Indicators : Management Approach and Policy. Yogyakarta, Indonesia. Gadjah Mada University Press. 1995. [Indikator Kinerja Pemda: Pendekatan Manajemen dan Kebijakan]. 